\title{
Phytoremediation Strategies for United Kingdom River Health in the Flood of Climate Change
}

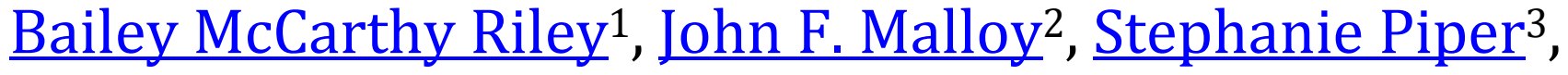 Theresa La ${ }^{4}$}

1Wayne State University, Department of Chemistry, 5101 Cass Ave, Detroit, MI

${ }^{2}$ Arizona State University, School of Earth and Space Exploration, 781 Terrace Mall, Tempe, AZ

3 University of California, Riverside, Department of Botany and Plant Sciences, 900 University Ave, Riverside, CA

${ }^{4}$ Case Western Reserve University, Department of Physiology and Biophysics, 2210 Circle Dr Robbins

Building, Cleveland, $\mathrm{OH}$

https://doi.org/10.38126/ISPG180209

Corresponding author: bfmccart@wayne.edu

Keywords: phytoremediation; rivers; nature-based; plants; community-based; UK; climate

Executive Summary: Industrialization and urbanization in the United Kingdom has led to practices that impact the quality of their river systems. In a recent 2020 report, $0 \%$ of rivers in England meet the current criteria of 'good health'. Climate change will increase the frequency of flooding and compound this alarming issue. Phytoremediation is a nature-based strategy that employs the use of plants to uptake waste materials such as heavy metals and antibiotic waste. Here, we recommend UK counties use phytoremediation-based strategies in conjunction with community involvement to improve river quality and make communities around river systems more resilient against the impacts of climate change.

\section{Introduction}

As one of the forefront nations of industrialization, the United Kingdom's rapid industry development and urbanization has led to environmental challenges that will be compounded by the effects of climate change. River pollution due to industrialization has been a long-standing issue, directly impacting those who live along the rivers and rely on them for water and agriculture. Prior to the Rivers Act of 1951, which rendered pollution into rivers an offence, studies documented eighty-nine different types of waste from different forms of trade in the city of Manchester (Klein 1956). In a 2019 report, only 15\% of rivers or other water bodies in England were classified as in 'good health' and capable of supporting sustainably healthy ecosystems, compared to $52 \%$ in Scotland, $44 \%$ in Wales, and 31\% in Northern Ireland ("B7. Surface Water Status" 2020). Furthermore, a recent September 2020 report found that with updated pollution criteria, $0 \%$ of England rivers are currently in 'good health.' ("Official Figures Reveal Not One River or Lake in England Is in Good Health" 2020). Modern challenges in England include dumping sewage treatment plant waste into rivers, of which there are over 200,000 documented occasions in 2019 (Laville and McIntyre 2020). The UK must act to meet the European Union stated goal of restoring clean river systems by 2027 ("EUR-Lex - 32000L0060 - EN - EUR-Lex" n.d.; "The Water Environment (Water Framework Directive) (England and Wales) Regulations 2017" n.d.).

Climate change will further intensify the consequences of river pollution on the health and resiliency of UK river systems. According to the Thames Estuary 2100 plan, flooding in the lower Thames watershed in England could increase by $40 \%$ due to increased rainfall in a warming climate (Penning-Rowsell et al. 2012), which will spread pollution far beyond today's boundaries. In response, 
the UK has set goals in their Water Framework Directive for all waters to achieve a healthy status by 2027 (L. Carvalho et al. 2019). While these strategies address the challenge of increased flooding, they focus solely on redirecting large volumes of stormflow water from flooding river channels and do not address pollution. An inexpensive parallel strategy to mitigate pollution is phytoremediation, a nature-based approach which removes pollutants from river systems via living plants. Here, we recommend using phytoremediation to mitigate risks posed by heavy metal and antibiotic pollutants exacerbated by climate-change-driven flood events in the UK. This recommendation proposes a pilot study in Europe within the River Thames river system. Additionally, by coupling this strategy with a community engagement plan, policymakers can include citizens in the vested health of their river systems.

\section{i. River Thames pollution}

The River Thames is an ideal location for a pilot phytoremediation effort due to its persistent challenges with pollution and recently approved flood channel project (Environment Agency 2016a). Of the 1,500 river systems encompassing over $200,000 \mathrm{~km}$ in the United Kingdom, the River Thames is the second longest at $346 \mathrm{~km}$ ("UK River and Flow Regimes" 2015). The river provides roughly $70 \%$ of the water utilized in the capital city of London, and many cities are centrally located around the river (Nickson et al. 2011).

The Thames has had longstanding challenges of heavy metal deposition into its waters due to urbanization and industrial practices. Heavy metals such as arsenic, cadmium, lead, mercury, and others are shown to cause organ damage with minimal exposure and are considered human carcinogens (Tchounwou et al. 2012). These dangerous effects led to the Clean Air Acts of 1956 and 1968 and the Clean Water Act of 1972, which placed significant regulations on industrialized activity and waste output into the air and river sources (Clean Air Act 1956 n.d., Clean Air Act 1968, n.d., Summary of the Clean Water Act 2013). Although these articles of legislation have improved the environment of the Thames, the river still faces significant heavy metal pollution challenges. Moreover, antibiotic waste poses an additional challenge to the Thames. Bacterial antibiotic resistance increases in the presence of heavy metals, leading to the possibility of deadly bacterial infections arising from increasing heavy metal pollution and spread due to flood events (Singer, Xu, and Keller 2019). UK policy makers can use the River Thames as a regional model for phytoremediation strategies via incorporation into current approved schemes and the development of community-based initiatives.

\section{ii. Phytoremediation}

Phytoremediation refers to a wide range of environmental cleaning efforts where living plants and algae are used as cleaning agents. This relatively new technology emerged at the end of the 20th century as a viable means of removing contaminants, including heavy metals, from a polluted area (Salt, Smith, and Raskin 1998). Incorporation of contaminants into plant species occurs through uptake via the root system or the leaf system. Once incorporated, these harmful chemical compounds can be broken down by enzymes found within plant tissues or stored within the plant (Sumiahadi and Acar 2018).

Several common plants native to the southern UK have been shown to take up a range of heavy metals (Table 1), including plants found presently in the southeastern UK in the Thames region such as horned pondweed (Zanichellia palustris) ("Zannichellia Palustris" n.d.). These plants can be classified as either metal indicators or metal hyperaccumulators. Metal indicator plants continuously uptake heavy metals into their leaves and shoots. When these plants die due to extremely high heavy metal concentrations, this indicates the presence of pollutants. To prevent heavy metals from returning to the environment, dead plants must be removed and disposed of (Gomes et al. 2016). These indicators provide a natural means of detecting heavy metal deposition events, and importantly work to remove heavy metals from the environment if proper disposal methods are utilized.

In contrast, metal hyperaccumulators do not die when heavy metals reach high concentrations; instead, they store heavy metals in their tissues without any negative health effects and are thus commonly used for phytoremediation (Sumiahadi and Acar 2018). In addition to removing heavy metals, some hyperaccumulators can accumulate antibiotics, which can serve to lessen the possibility of increased antibacterial resistance within the Thames ecosystem. 
Phytoremediation has proven useful in many locations around the world (Sumiahadi and Acar 2018), such as Torch Lake in Michigan, United States of America, where sunflowers (Helianthus) were used to remove copper from mining-contaminated sediments (Li and Ramakrishna 2011). However, implementation in the UK is lacking (Leggo 2017). We recommend for the UK to implement phytoremediation within the River Thames river system; specifically, that metal indicators and metal hyperaccumulators be used in tandem along with careful clean up and disposal of heavy metal contamination.

\section{iii. Specific plants}

Specifically, we recommend that sage pondweed (Stuckenia pectinata), horned pondweed ( $Z$. palustris), common reed (Phragmites australis), and cordgrass (Spartina maritima) be used as heavy metal indicators (Sumiahadi and Acar 2018). These plants incorporate Lead (Pb), Cadmium (Cd), Mercury (Hg), Nickel (Ni), Copper (Cu), and Zinc (Zn) (P. N. Carvalho, Basto, and Almeida 2012; Sumiahadi and Acar 2018). Additionally, we recommend the use of needle spikerush (Eleocharis acicularis), bulrush (Typha latifolia), and sunflowers (Helianthus) as hyperaccumulators to use within the Thames ecosystem. These plants incorporate Iron (Fe), Manganese (Mn), Chromium (Cr), Aluminium (Al), $\mathrm{Cu}, \mathrm{Pb}, \mathrm{Ni}, \mathrm{Cd}$, and Zn (Bansal 2013; Datta et al. 2013; Yang and Shen 2020), and uptake efficiency increases when combined together (Kumari and Tripathi 2015). Sunflowers also function as antibiotic accumulators, collecting tetracycline (TC), oxytetracycline (OTC), and chlortetracycline (CTC) from the environment (Zhou, Tang, and Wu 2013; Datta et al. 2013).) All plants recommended here are commonly found in wetlands and saturated soils within the UK. Both needle spikerush and cordgrass are native species to the UK, while the others are naturalized (Table A1).

The UK's current Biodiverse Action Plan (BAP) does not include any of the proposed plant species for conservation in the UK, but are all noninvasive and can coexist with other plants tabled in the BAP ("List of UK BAP Priority Vascular Plant Species" 2007). Furthermore, species such as the common reed, needle spikerush, cordgrass, and bulrushes would not require seasonal replanting and would only need

www.sciencepolicyjournal.org to be replaced if a hyperaccumulation event from high heavy metal concentrations occurred.

\section{Recommendation one: incorporate phytoremediation strategies into general planning via the River Thames Scheme}

The River Thames Scheme is an initiative from seven municipal councils to address the threats of flooding and loss of property along a stretch of the River Thames ("Lower Thames Flood Risk Management Strategy" 2010). The scheme incorporates flood channels, basins intended to capture overflow water in the case of extreme weather into the River Thames. Furthermore, the scheme includes developing at least 40 hectares of biodiverse habitat along the riverbed that include shallow areas meant for reedbed population and new trees and shrubs alongside the modified land (Environment Agency 2016b). Implementers can consider these previously determined habitats for phytoremediation-based flora. This recommendation benefits from the resources of an already-funded scheme set to begin construction in 2023, allowing for time to incorporate phytoremediation-based plants amongst other BAPapproved flora ("River Thames Scheme: Reducing Flood Risk from Datchet to Teddington" n.d.). The overall project is estimated at 640 million pounds, with 237 million currently secured from the Surrey County Council (SCC 2019).

\section{Mapping critical need areas for remediation}

Three heavy metal polluter regions along the River Thames were identified in 2016 by the European Environmental Agency's USEtox model, a predictor for heavy metal depositions to air and water in Europe, which can target areas for phytoremediation ("Environmental Pressures of Heavy Metal Releases from Europe's Industry" 2018). All three of these pollution sources are wastewater treatment plants and considered points of concentration of the surrounding region's waste. We recommend incorporating the seven plants mentioned in Table A1 in three specific regions: Mogden Water Treatment Plant, Thames Water Utilities Beckton, and Thames Water Utilities Crossness (Figure A1). The Mogden treatment plant is located within the current River Thames Scheme and pipes treated wastewater to Isleworth Ait, providing an opportunity for planting around the isle itself and straightforward incorporation into the scheme. The Beckton and Crossness plants are outside of the scheme and can be 
approached via community-based remediation efforts.

\section{Recommendation two: include community- based strategies for phytoremediation at heavy pollution sites}

\section{i. Community-based strategies}

Although the River Thames Scheme provides a useful strategy that could readily include phytoremediation, the strategy does not begin until 2023. In the meantime, community-based strategies could be readily implemented at recognized heavy pollution sites that also lie within the Thames Strategy zone.

\section{ii. Community engagement policy}

A crucial addition to nature-based phytoremediation development strategies is a community action plan. We specifically recommend recruiting community members to monitor and report on phytoremediation areas, making it possible for land managers to quickly respond to heavy metal indicator plant death or hyperaccumulator planting. Community involvement can start early in the planning stages of the scheme. Community leaders are most familiar with their own neighborhood or city and can help identify ideal places for planting indicators and hyperaccumulators, as well as areas where these plants already grow. Then, citizen-based surveyors will report plant health to land managers and river engineers to aid in phytoremediation efforts. Recruiting the community for establishing phytoremediation areas would also instill a sense of ownership in the community. We suggest that the Surrey County Council, the government organization funding the first phase of the River Thames Scheme, oversee this citizen surveyor program.

Citizens and practitioners, like land managers or project organizers, also often perceive different priorities in community-based projects (Swapan 2014). For example, leaders often prioritize environmental or restoration policy in order of environmental need. However, actions taken in these areas may not be publicly visible, so citizens do not see progress and feel less support for their leaders. Therefore, bridging this priority gap by connecting citizens and leaders can increase long-term support from the community and improve the odds of success of the project. Previous work to understand the most successful public participation strategies, such as monitoring environmental quality and advocating for policy development (Hu et al. 2017), include providing incentives to promote public participation. 'Adopting' abandoned yards and road medians in cities limits overgrown lots, therefore reducing blight and social disparities. Public participation also limits the pressure on city leadership by leveraging the help of volunteers. Native planting programs can mobilize hundreds of volunteers to complete restoration work and lead to a feeling of connectedness to environmental successes. However, it is crucial in all cases to avoid the focus on simply failure or success (Boland and Zhu 2012). Slight progress is better than no progress. Community engagement with phytoremediation will need to be a long-term effort, especially when monitoring populations of indicator species. Pairing citizen science and engagement with land managers is central to a successful phytoremediation plan in the River Thames.

Community engagement should also allow citizen advocates to play a major role in environmental policy decisions. While institution-led monitoring successfully informs policy at the regional and national scale in the UK, decisions based on this work typically take three to nine years to implement. Natural resource decisions have a larger effect on the local scale; locals will benefit the most from phytoremediation in their own area. Monitoring work at the village scale involving local people is much more effective and has led to decisions implemented within a year (Danielson et al. 2010). This result is often due to the sense of ownership within the community that leads to increased advocacy and accountability for local policymakers.

We recommend land managers and River Thames Scheme engineers work directly with citizens living on the River Thames at every level of planning to ensure mutual benefits. While planting and establishing these phytoremediation areas is the top priority, and fits seamlessly into this already funded project, community engagement would strengthen this project in the eyes of the public and in overall river health. Phytoremediation efforts will be most effective with consistent community monitoring and communication with land managers. Further, when indicators need to be removed to prevent downstream pollution, citizens can help with removal, disposal, and replanting. The River Thames Scheme will be modifying the land, and in conjunction 
with flood protection, phytoremediation will further serve the community.

\section{Conclusion}

Phytoremediation is one of several strategies that the UK will need to incorporate to meet its 2027 goal of having all river systems in a healthy state. Our policy proposal prioritizes the incorporation of phytoremediation as part of the River Thames Scheme. Community involvement is an important complement for longevity and public support of this project.
If this strategy is successful, the UK can readily expand and incorporate these actions into future flood channel plans and individual community initiatives. Furthermore, communities without resources for council-based management can still use the plants listed under Table $\mathrm{A} 1$ as a starting point to participate in community-based endeavors. This strategy will improve the health and resiliency of the UK's river systems through nature-based pollution remediation and increase community interest in river quality.

\begin{tabular}{|c|c|c|c|c|c|c|c|}
\hline \multicolumn{8}{|l|}{ Appendix } \\
\hline & $\begin{array}{l}\text { Sago pondweed } \\
\text { (Stuckenia } \\
\text { pectinata) }\end{array}$ & $\begin{array}{l}\text { Horned pondweed } \\
\text { (Zanichellia } \\
\text { palustris) }\end{array}$ & $\begin{array}{c}\text { Common reed } \\
\text { (Phragmites } \\
\text { australis) }\end{array}$ & $\begin{array}{l}\text { Needle spikerush } \\
\text { (Eleocharis } \\
\text { acicularis) }\end{array}$ & $\begin{array}{l}\text { Cordgrass } \\
\text { (Spartina } \\
\text { maritima) }\end{array}$ & $\begin{array}{c}\text { Sunflower } \\
\text { (Helianthus) }\end{array}$ & $\begin{array}{l}\text { Bulrush } \\
\text { (Typha } \\
\text { latifolia) }\end{array}$ \\
\hline $\begin{array}{l}\text { Indicator or } \\
\text { Accumulator? }\end{array}$ & Indicator & Indicator & Indicator & $\begin{array}{c}\text { Hyper- } \\
\text { accumulator }\end{array}$ & Indicator & $\begin{array}{l}\text { Hyper- } \\
\text { accumulator }\end{array}$ & $\begin{array}{l}\text { Hyper- } \\
\text { accumulator }\end{array}$ \\
\hline $\begin{array}{l}\text { Metals } \\
\text { Uptaken }\end{array}$ & $\mathrm{Pb}, \mathrm{Cd}, \mathrm{Hg}, \mathrm{Ni}$ & $\mathrm{Pb}, \mathrm{Cd}, \mathrm{Hg}, \mathrm{Ni}$ & $\mathrm{Pb}, \mathrm{Cd}, \mathrm{Cu}, \mathrm{Zn}$ & As, $\mathrm{Cd}, \mathrm{Cu}, \mathrm{Zn}$ & $\mathrm{Pb}, \mathrm{Cd}, \mathrm{Cu}, \mathrm{Zn}$ & $\mathrm{Cd}, \mathrm{Pb}$ & $\begin{array}{l}\mathrm{Cd}, \mathrm{Cr}, \mathrm{Cu}, \mathrm{Fe} \\
\mathrm{Ni}, \mathrm{Pb}, \mathrm{Zn}\end{array}$ \\
\hline $\begin{array}{l}\text { Antibiotics } \\
\text { Uptaken }\end{array}$ & & & & & & $\begin{array}{l}\mathrm{TC}, \mathrm{OTC}, \mathrm{CTC} \\
\text { from aqueous } \\
\text { medium }\end{array}$ & \\
\hline $\begin{array}{c}\text { Current } \\
\text { Distribution } \\
\text { in UK }\end{array}$ & $\begin{array}{l}\text { Britain and } \\
\text { Ireland }\end{array}$ & $\begin{array}{l}\text { Native, } \\
\text { Throughout UK }\end{array}$ & $\begin{array}{l}\text { Native to } \\
\text { British Isles }\end{array}$ & $\begin{array}{l}\text { Throughout } \\
\text { UK }\end{array}$ & $\begin{array}{l}\text { South England, } \\
\text { Ireland }\end{array}$ & $\begin{array}{c}\text { Throughout UK, } \\
\text { Naturalized }\end{array}$ & $\begin{array}{l}\text { Native, } \\
\text { Throughout UK }\end{array}$ \\
\hline
\end{tabular}

Table A1: Proposed species for phytoremediation initiatives in the UK. 


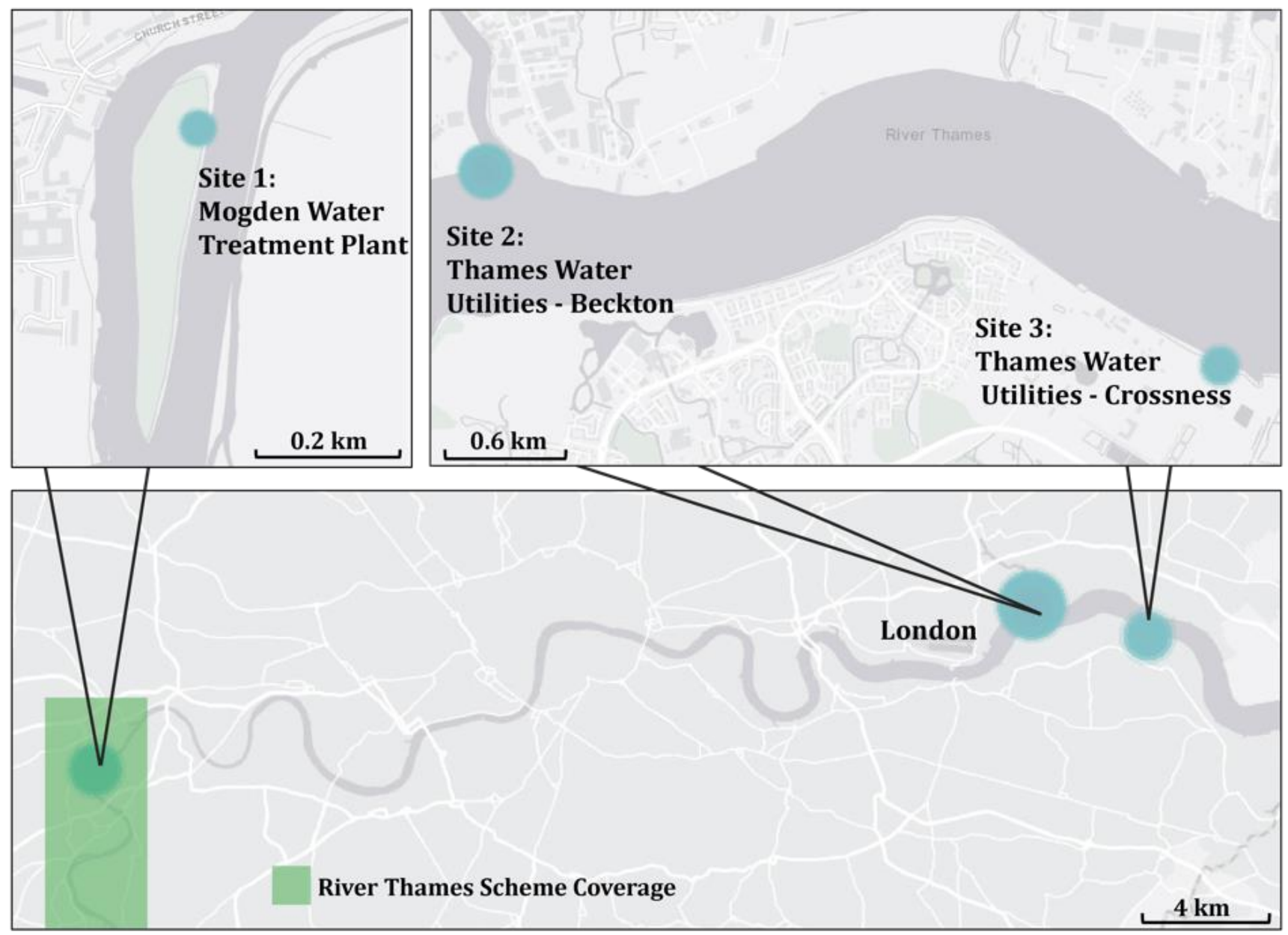

Figure A1: Proposed sites for initial phytoremediation efforts (adapted from EEU USETox Model).

\section{References}

"B7. Surface Water Status." 2020. Joint Nature Conversation Committee. October 15, 2020. https://incc.gov.uk/our-work/ukbi-b7-surfacewater-status/.

Bansal, Om Prakash. 2013. "Green Remediation of Tetracyclines in Soil-Water Systems." Health 05 (12): 2039-44. http://doi.org/10.4236/health.2013.512276

Boland, Alana, and Jiangang Zhu. 2012. "Public Participation in China's Green Communities: Mobilizing Memories and Structuring Incentives." Geoforum; Journal of Physical, Human, and Regional Geosciences 43 (1): 147-57. https://doi.org/10.1016/i.geoforum.2011.07.010

Carvalho, Laurence, Eleanor B. Mackay, Ana Cristina Cardoso, Annette Baattrup-Pedersen, Sebastian Birk, Kirsty L. Blackstock, Gábor Borics, et al. 2019. "Protecting and Restoring Europe's Waters: An Analysis of the Future Development Needs of the Water Framework Directive." The Science of the Total Environment 658 (March): 1228-38. https://doi.org/10.1016/j.scitotenv.2018.12.255
Carvalho, Pedro N., M. Clara P. Basto, and C. Marisa R. Almeida. 2012. "Potential of Phragmites Australis for the Removal of Veterinary Pharmaceuticals from Aquatic Media." Bioresource Technology 116 (July): 497-501.

https://doi.org/10.1016/j.biortech.2012.03.066

Clean Air Act 1956. n.d. Accessed January 7, 2021. https://www.legislation.gov.uk/ukpga/Eliz2/45/52/enacted.

Clean Air Act 1968. n.d.

https://www.legislation.gov.uk/ukpga/1968/62/ pdfs/ukpga 19680062 en.pdf.

Danielson, Mats, Love Ekenberg, Aron Larsson, and Mona Riabacke. 2010. "Transparent Public Decision Making: Discussion and Case Study in Sweden." In E-Democracy: A Group Decision and Negotiation Perspective, edited by David Rios Insua and Simon French, 263-81. Dordrecht: Springer Netherlands. https://doi.org/10.1007/978-90-481-9045-4 15 
Datta, Rupali, Padmini Das, Stephanie Smith, Pravin Punamiya, Dil M. Ramanathan, Ramana Reddy, and Dibyendu Sarkar. 2013. "Phytoremediation Potential of Vetiver Grass [Chrysopogon Zizanioides (L.)] for Tetracycline." International Journal of Phytoremediation 15 (4): 343-51. https://doi.org/10.1080/15226514.2012.702803

Environment Agency. 2016a. "River Thames Scheme." GOV.UK. March 4, 2016.

https://www.gov.uk/government/collections/riv er-thames-scheme.

Environment Agency. 2016b. "River Thames Scheme: Key Features Map and Channels." GOV.UK. March 4, 2016.

https://www.gov.uk/government/publications/ri ver-thames-scheme-key-features-map-andchannels.

"Environmental Pressures of Heavy Metal Releases from Europe's Industry." 2018. April 18, 2018. https://www.eea.europa.eu/themes/industry/ind ustrial-pollution-in-europe/heavy-metalpollution.

"EUR-Lex - 32000L0060 - EN - EUR-Lex." n.d. Accessed March 10, 2021. https://eur-lex.europa.eu/legalcontent/EN/TXT/?uri=CELEX:32000L0060.

Gomes, Maria Angélica da Conceição, Rachel Ann Hauser-Davis, Adriane Nunes de Souza, and Angela Pierre Vitória. 2016. "Metal Phytoremediation: General Strategies, Genetically Modified Plants and Applications in Metal Nanoparticle Contamination." Ecotoxicology and Environmental Safety 134 (December): 133-47. https://doi.org/10.1016/i.ecoenv.2016.08.024

$\mathrm{Hu}$, Wenyou, Yanxia Zhang, Biao Huang, and Ying Teng. 2017. "Soil Environmental Quality in Greenhouse Vegetable Production Systems in Eastern China: Current Status and Management Strategies." Chemosphere 170 (March): 183-95. https://doi.org/10.1016/j.chemosphere.2016.12.047

Klein, L. 1956. "The Problems of River Pollution in Industrial Areas." Royal Society of Health Journal 76 (7): 348-57; passim. https://doi.org/10.1177\%2F1466424056076007 $\underline{11}$

Kumari, Menka, and B. D. Tripathi. 2015. "Efficiency of Phragmites Australis and Typha Latifolia for Heavy Metal Removal from Wastewater." Ecotoxicology and Environmental Safety 112 (February): 80-86. https://doi.org/10.1016/i.ecoenv.2014.10.034

Laville, Sandra, and Niamh McIntyre. 2020. "Exclusive: Water Firms Discharged Raw Sewage into England's Rivers 200,000 Times in 2019." The Guardian, July 1, 2020. http://www.theguardian.com/environment/2020 /jul/01/water-firms-raw-sewage-england-rivers. Leggo, P. 2017. "The Neglect of Phytoremediation in the
UK: A Sorry State of Affairs." Journal of Fisheries \& Livestock Production 5 (2): 0-1. https://doi.org//10.4172/2332-2608.1000227

Li, Kefeng, and Wusirika Ramakrishna. 2011. "Effect of Multiple Metal Resistant Bacteria from Contaminated Lake Sediments on Metal Accumulation and Plant Growth." Journal of Hazardous Materials 189 (1-2): 531-39. https://doi.org/10.1016/i.jhazmat.2011.02.075

“List of UK BAP Priority Vascular Plant Species." 2007. Joint Nature Conversation Committee. https://data.jncc.gov.uk/data/98fb6dab-13ae470d-884b-7816afce42d4/UKBAP-priorityvascular-plants.pdf.

"Lower Thames Flood Risk Management Strategy." 2010. Environment Agency - Thames Region. https://assets.publishing.service.gov.uk/governm ent/uploads/system/uploads/attachment data/fi le/496416/LIT 10385.pdf.

Nickson, Alex, Andrew Tucker, Cecilia Liszka, David Gorzelany, David Hutchinson, Isabel Dedring, Kevin Reid, et al. 2011. “Securing London's Water Future." Mayor of London. https://www.london.gov.uk/sites/default/files/gl a migrate files destination/water-strategyoct11.pdf.

"Official Figures Reveal Not One River or Lake in England Is in Good Health." 2020. September 17, 2020. https://www.wcl.org.uk/not-one-river-inengland-in-good-health.asp.

Penning-Rowsell, Edmund C., Nick Haigh, Sarah Lavery, and Loraine McFadden. 2012. "A Threatened World City: The Benefits of Protecting London from the Sea." Natural Hazards 66 (3). https://doi.org/10.1007/s11069-011-0075-3.

"River Thames Scheme: Reducing Flood Risk from Datchet to Teddington." N.d. Accessed January 7, 2021.

https://www.gov.uk/government/publications/ri ver-thames-scheme-reducing-flood-risk-fromdatchet-to-teddington/river-thames-schemereducing-flood-risk-from-datchet-to-teddington.

Salt, D. E., R. D. Smith, and I. Raskin. 1998. "PHYTOREMEDIATION." Annual Review of Plant Physiology and Plant Molecular Biology 49 (June): 643-68.

SCC. 2019. "River Thames Scheme Funding Announced as Part of Surrey Flood Alleviation Programme." October 21, 2019. https://news.surreycc.gov.uk/2019/10/21/riverthames-scheme-funding-announced-as-part-ofsurrey-flood-alleviation-programme/. 
Singer, Andrew C., Qiuying Xu, and Virginie D. J. Keller. 2019. "Translating Antibiotic Prescribing into Antibiotic Resistance in the Environment: A Hazard Characterisation Case Study." PloS One 14 (9): e0221568.

https://doi.org/10.1371/journal.pone.0221568

Sumiahadi, A., and R. Acar. 2018. "A Review of Phytoremediation Technology: Heavy Metal Update by Plants." IOP Conference Series: Earth and Environmental Science. https://iopscience.iop.org/article/10.1088/17551315/142/1/012023/pdf. https://doi.org/10.1088/17551315/142/1/012023

Summary of the Clean Water Act. 2013. https://www.epa.gov/lawsregulations/summary-clean-water-act. Swapan, Mohammad Shahidul Hasan. 2014. "Realities of Community Participation in Metropolitan Planning in Bangladesh: A Comparative Study of Citizens and Planning Practitioners' Perceptions." Habitat International 43 (July): 191-97. https://doi.org/10.1016/j.habitatint.2014.03.004 Tchounwou, Paul B., Clement G. Yedjou, Anita K. Patlolla, and Dwayne J. Sutton. 2012. "Heavy Metal Toxicity and the Environment." Experientia. Supplementum 101: 133-64. https://doi.org/10.1007\%2F978-3-7643-8340$\underline{46}$

Bailey McCarthy Riley is an Analytical Chemistry PhD candidate at Wayne State University in Detroit, Michigan. Her work develops microfluidic devices for the detection of ultralow concentration analytes with a focus towards diagnostic and pharmaceutical quality control applications. She is a member of the Detroit Science Policy Network and a National Science Policy Network SciPol Scholars fellow at Annual Reviews, where she translates review articles to science policy.

John Malloy (he/him) is a PhD candidate studying Astrobiology and Complex Systems Science at Arizona State University. He studies the fundamental nature and definition of life, both on Earth and on other planets, through exploring the evolution of biochemistry and life-like chemical systems. He is working to predict future evolutionary steps and create a universal definition of evolution. He is also a member of the Arizona Science Policy Network, where he works to advance science-based policy measures in Arizona. He enjoys training for and competing in ultramarathons across the American Southwest.

Stephanie Piper is a fourth-year PhD candidate at University of California, Riverside in the Department of Botany and Plant Sciences studying urban atmospheric nitrogen and the roles plants play. She is the current co-chair of UCR Science to Policy and is a policy fellow in the California Assembly Committee on Water, Parks, and Wildlife focused on community engagement in the Salton Sea.

Theresa La is a current second-year MSMP student at Case Western Reserve University. Her research focuses on health disparities, particularly in immigrant communities and elderly population. She is founder of the Union of Concerned Scientist Orange County Team where she organizes local scientists for policy advocacy.

www.sciencepolicyjournal.org

JSPG, Vol. 18, Issue 2, June 2021 


\section{Acknowledgments}

Thank you, Christopher Jackson, Sindhu Nathan, Fiona Dunn, Rachel Starr, and Meredith Ward, for edits. Also, thank you William Ota for organizing a collection of early career scientists interested in proposing and implementing policy-based solutions to climate change. 